\title{
Analysis of Quota System of Admission (QSA) and the Challenge of Sustainable National Unity in Nigeria
}

\author{
Jordan. C. Ogoke Rev. Fr. Dr. G. C. Abiogu \\ Department of Educational Foundations University of Nigeria Nsukka, Enugu State Nigeria
}

\begin{abstract}
This paper analyzed quota system of admission in relation to building of sustainable national unity in Nigeria. The introduction of quota system of admission in Nigeria's educational sector came due to the desire to ensure that those areas of Nigeria believed to be educationally disadvantaged are aided to achieve through education, similar socio-economic development as their counterparts and thus pacify violent agitations emanating from these areas of the country perceived to be instigating disunity in the country. However, when critically analyzed it was discovered that quota system of admission is riddled with inherent pitfalls that amount to serious threat to successful building of sustainable national unity. Such pitfalls inherent in quota system of admission include: violation of applicants' equal rights to education as provided for in the 1999 constitution as well as operating a discriminatory admission process that works to favour some school applicants from particular states more than others. Given the above, the researchers argued that application of quota system to school admissions in Nigeria is antithetical to any attempt aimed at building a sustainable national unity in Nigeria. Accordingly, it was recommended that implementation of quota system of admission in Nigeria's education system be discontinued immediately, budgetary allocation to the educational sector be increased in line with UNESCO's $26 \%$ benchmark to enable building of enough schools to accommodate the ever-increasing number of qualified school applicants. Keywords: Quota System of Admission, National Unity, Sustainable National Unity.
\end{abstract}

DOI: $10.7176 / \mathrm{JEP} / 11-30-03$

Publication date:October $31^{\text {st }} 2020$

\section{Introduction}

An enduring national unity has been one of the key goals of Nigeria since her independence. The reason is not farfetched especially given that an enduring national unity is regarded as a conditio sine qua non (an essential condition) for sustainable development. National unity is a condition wherein the citizens of a country consisting of diverse ethnic groups, religious beliefs and regions co-exist peacefully as one united country in accordance with given national ideology and federal constitution (Chang, Azizan \& Amran, 2013). For the above authors, ensuring national unity in any country often requires collective efforts of both government and the citizens. However, creating a suitable environment in which national unity thrives is an important duty of any responsible government. This very important duty of the government is often discharged in line with extant laws and/or government policies. Expectedly, sections 18(1) and 42(1) of the 1999 constitution of the federal republic of Nigeria as amended were designed to guarantee all school applicants in Nigeria through equal rights and provision of adequate educational opportunities, a level playing ground as steps in the right direction towards providing an enabling environment for upholding national unity (FRN, 1999). To further ensure that various disuniting forces like; the initial lopsided educational advancement which seems to have placed some regions in Nigeria at vantage positions and as well occasioned uneven socio-economic development are weakened, the quota system principle was reinstituted by federal government of Nigeria. The quota system principle was once operational during the colonial rule in Nigeria but resurfaced in post-colonial Nigeria as an upshot of the constitution drafting committee, inaugurated during the military presidency of Murtala Mohammed in 1975 (Onwuka, 1997). The reintroduction of the quota system principle in post-colonial Nigeria was a response to the forces of multiethnicity of the new independent state. Nigeria's multiethnic nature as well as the initial uneven educational advancement was regarded as potent centrifugal force due to the endemic problems of acrimonious existence as witnessed among the diverse groups and interests, often resulting to mutual distrust, inter-ethnic conflicts, fear of domination of one ethnic group over another and instability steering towards possible disintegration of the polity.

The above are believed to have made expedient, the need for national integration as it applies to building a unified nation-state out of the desperate ethnic and geographic elements by ensuring that every part of the county is carried along. It was however not long after the reinstitution of the quota system principle that it found its way into the educational sector. As a principle to be applied to students' admission into federal government owned schools, it is to help address disparities in educational attainments of different areas of the country and inequalities in socio-economic development which create perennial acrimonies promoting disunity in Nigeria. However, it is regrettable to note that with more than forty years gone since the introduction of the quota system of admission in Nigeria's educational sector, the problem of inequality among various regions with regard to educational advancement cum socio-economic development seem to have continued to linger. Thus, aggravating further agitations by some ethnic groups and/or regions in Nigeria especially non-beneficiaries of the quota system of 
admission, questioning the justification for the continual implementation of the quota system of admission in the educational sector. Efforts aimed at building sustainable national unity in Nigeria seems to have been undermined as well. This situation has over the years been a source of worry to various well-meaning Nigerians and has also served as an impetus agitat (motivating factor) to the researchers to attempt an analysis of the quota system of admission vis-à-vis building of sustainable national unity in Nigeria. Before proceeding further, the main thrust of the paper (quota system of admission) will be expounded to ensure easy understanding.

\section{Quota system of admission: meaning and guidelines}

Quota system of admission has since its inauguration by the federal government of Nigeria attracted attentions of various scholars and commentators. This is due to its contentious nature. Hence, it has variously been construed in many ways, accounting for the very many available definitions. Quota system as implemented in the educational sector is considered a system of admitting certain number of candidates from each state of the country into schools in one academic year (Odigwe \& Swem, 2016). Notably, the basis for admitting these applicants under quota system according to Ogoke, Onwuka and Enemuo (2019) is not solely on merit but on other criteria like state and/or local government of origin. Hence, it is worthy of note that under the quota system of admission, state of origin plays an important role with regard to who is to be admitted into federal government owned schools. In other words, representation of various states in the distribution of opportunities for education is to be given important consideration under the quota system of admission.

As a way of grouping states into possible beneficiaries of quota system of school admission, states were divided into educationally advantaged areas and educationally disadvantaged areas. Educationally advantaged areas are regarded as areas with significant number of educated persons due to little or no financial, cultural and religious handicaps faced by individuals in their educational pursuit while educationally disadvantaged areas are places where the percentage of people who have received formal education at all levels is comparatively low due to the prevalent financial, cultural and religious handicaps faced by individuals in the area (Onwuka, 1997). For this reason, educationally disadvantaged areas receive concessions for school admissions at different levels as a way of encouragement and ensuring that more applicants from the area are given opportunities for admission into school. With this, it is expected that the disadvantages and such socio-economic implications it holds for them will be gradually addressed.

To implement the quota system of admission at various levels of education, some guidelines were outlined by the federal government of Nigeria. The admission guidelines as it is currently implemented in unity secondary schools prescribes the following cutoff marks: Abia state 130; Adamawa state 62; Akwa-Ibom state 123; Anambra state 139; Bauchi state 35; Bayelsa state 72; Benue state 111; Borno state 45; Cross River state 97; Delta state 131; Ebonyi state 112; Edo state 127; Ekiti state 119; Enugu state 134; Gombe state 58; Imo state 138; Jigawa state 44; Kaduna state 91; Kano state 67; Katsina state 60; Kebbi state 9 (male) 20 (female); Kogi state 119; Kwara state 123; Lagos state 133; Nasarawa state 58; Niger state 93; Ogun state 131; Ondo state 126; Osun state 127; Oyo state 127; Plateau state 97; Rivers state 118; Sokoto state 9 (male) 13 (female); Taraba state 3 (male) 11 (female); Yobe state 2 (male) 27 (female); Zamfara state 4 (male) 2 (female) and FCT Abuja 90 (Onyekwelu, 2020).

At the tertiary level, the quota system of admission guidelines provides for forty-five percent $(45 \%)$ of students' admissions to be based on merit as determined by the Unified Tertiary Matriculation Examination (UTME) scores, twenty (20\%) for applicants from educationally disadvantaged states and thirty-five percent (35\%) for applicants from catchment areas (Salim, 2003). The above according to Omeje, Egwa and Adikwu, (2016) imply that forty-five percent $(45 \%)$ of the available spaces are reserved for applicants with very higher marks with no recourse to state of origin or gender. These applicants are first given considerations for first choices of course and institution before others. Twenty percent $(20 \%)$ of admission slots is to be reserved for applicants who are from states designated as educationally disadvantaged areas which are predominantly made up of states in the northern part of Nigeria. The catchment areas have thirty five percent (35\%) of the admission slots, and this is for applicants within the geographical and sociocultural area hosting or contiguous to the institution of the applicant's choice. The above guidelines with regard to students' admission into federal government owned educational institutions in Nigeria are considered lopsided. So, it is believed that school admissions based on the above guidelines cannot consolidate efforts directed at building and ensuring a lasting peace for national unity but can only serve as a stumbling block. Consequently, an attempt to identify (with the view to addressing) the challenges associated with quota system of admission with respect to building sustainable national unity becomes imperative.

\section{Quota system of Admission and the Challenge of Building Sustainable National Unity in Nigeria}

An attempt to identify the challenges posed by the quota system of admission to achieving sustainable national unity in Nigeria becomes imperative as a result of the fact that the rationale behind its introduction seems to be far from being realized after decades of being in existence. Introduced to aid states that are lagging behind in educational advancement to achieve substantial socioeconomic development and, in the process, ensure sustainable national integration and unity; the quota system of admission seems to have rather constituted a serious 
threat to the sustainability of Nigeria unity. The above is true given that its implementation has occasioned a continual violation of the principle of equal rights and has as well shown a lack of commitment by successive Nigerian governments to fulfilling their statutory duty of providing adequate educational opportunities for every citizen at all levels devoid of any special regards to or against any applicant based on such reasons like ethnicity as provided for in sections 18 (1) and 42 (1) of the 1999 constitution of the federal republic of Nigeria. Any policy of the government like the quota system of admission which seems to violate the constitutional rights of some of its citizens due to their state of origin cannot be considered a viable tool for facilitating an enduring national integration. The government will rather be presented in a bad light vis-à-vis its sincerity and commitment to achieving such crucial goals like building of sustainable national unity. Expectedly, as it is the case in Nigeria today there is a loss of faith in such a government and/or system which perpetrates the methodical violation of the constitutional rights of some of its own citizens only to uphold that of others. Consequently, rather than regarding quota system of admission as a policy of national integration and unity, it has been viewed by many as a seed of violent revolution in the future (Onwubiko, 2014). This is true, because there is a limit of tolerance expected from people who are continually denied of the rightful opportunity to pursue their dreams of obtaining education for a better future. When this limit is crossed, there will be nothing but violent agitations, a situation known to be antithetical to building and sustaining national unity.

Also, quota system of admission through its modus operandi (mode of operation) is considered to be capable of turning one group or region against the other. As argued by Enemuo (2004), the quota system of admission encourages social discrimination of one group against the other. This is true because it is the practice of favouring some school applicants at the expense of others in school admissions on the basis of state or local government of origin. Validating the above Imhanlahimi and Maduewesi (2006) report that more than seventy percent (70\%) of Nigerians who apply for admission into schools every year are denied of admission opportunities not because they are not qualified but because certain factors like the quota system militate against their gaining of admission. Hence, the emphasis attached to one's state of origin under the quota system of admission is considered destabilizing and does not in any way work to promote sustainable national unity in Nigeria (Enemuo, 2004).

Furthermore, using collective resources of a country to run educational institutions only to deny some qualified applicants of admission opportunities into schools on the basis of state of origin is unacceptable. It is an action that cannot under any circumstance engender the needed harmonious environment that will drive national unity. Qualified school applicants who under the quota system are denied admission into schools as a result of their state of origin are often aggrieved. Not only does the operation of the quota system of admission aggrieve affected school applicants, it also goes ahead to inflict pains and feelings of marginalization on the various families of the affected school applicants. A country where many of its citizens especially those from particular region or states feel marginalized will likely not be a safe haven for peace and national unity. The above pitfalls of the quota system of admission which pose a great threat to educational development as well as sustainable unity in Nigeria no doubt informs and justifies the rationale behind the declaration of the then minister of education Jibril Amino that "no state would be regarded as educationally disadvantaged after ten years of the introduction of quota system of admission" (Onwuka, 1997). The declaration again corroborates the fact that with regard to achieving sustainable national unity, the quota system of admission is inherently flawed and would not be applied to students' admission ten years after its implementation. However, it seems like the quota system of admission in Nigeria's educational system has come to stay as it has continued to serve as a method of admission into different levels of education even after more than forty years of its implementation. This situation is one that has continued to produce a soar taste in the mouths of most Nigerians (especially those from areas of the country tagged "educationally advantaged"), who regard the quota system of admission as a means of perpetually marginalizing and keeping them down. It is therefore paramount that a new approach be conversed in order to ensure that the much-needed environment that will ensure sustainable national unity is entrenched.

\section{The way forward}

As a way forward to building and sustaining the much-needed national unity in Nigeria, there is need for sustainable peace. Peace is known to be a precondition for sustainable national unity (Antonio, 2019). This means that without peace, achieving unity at any level becomes almost impossible. Thus, to engender peace especially in a multiethnic state like Nigeria, it is expected that the distribution of opportunities for social benefits like education be carried out in ways that will guarantee equity and fairness. When equity and fairness are guaranteed, school applicants (irrespective of state of origin) will be afforded a level playing ground which is believed not to be guaranteed under the quota system of admission. With this, fears or feelings of marginalization will be allayed and peace will be restored. Of course, an environment that is to create peace is one where majority of individuals from various creeds are happy because of the faith they have in a system that is devoid of favouritism and discrimination.

Again, an increased annual budgetary allocation to the educational sector should be prioritized by the Nigeria government. This is necessary in order to help address the problem of limited number of affordable schools to admit the ever-increasing number of applicants every year. With enough funds, more schools will be built and the 
carrying capacities of existing ones will be enhanced as well. It will also take care of the employment of enough teachers and the provision of adequate infrastructural facilities to carter for the instructional and research needs of students at different levels of education all over the country. Limited number of affordable educational institutions and facilities in Nigeria are no doubt among the major reasons behind the limited admission spaces and another justification for the subsequent introduction of such policy like the quota system of admission. Perhaps if it wasn't for the above reasons, the issue of quota system of admission would not have been contemplated or necessitated. So, if the issues of inadequate funding as well as limited number of schools and facilities are taken care of, opportunities for admitting more students will be created and the problem of rationing school admissions and the consequent disagreements and internal strife will be resolved ones and for all.

\section{Conclusion}

As a way of discharging the important role of building a state characterized by sustainable national unity, the federal government of Nigeria through its policy of quota system of admission has tried to ensure that school applicants from particular areas of the country are given similar educational opportunities as their counterparts. This is to afford them comparable opportunities for socioeconomic development, dissipate grievances that otherwise may arise as well as promote harmony for sustainable national unity in a multiethnic state like Nigeria. However, the quota system of admission has given rise to $a$ discriminatory admission process that works to favour some school applicants from particular states more than others as well as a violation of section 18(1) of Nigeria's constitution which provides for equal rights to be enjoyed by every school applicant. Based on the above, the quota system of admission is believed to have failed in promoting equity or creating the much-needed peaceful environment in Nigeria. Thus, this paper concludes that the quota system of admission by its operations pose a serious threat to national unity in Nigeria and until this is resolved; the much-needed atmosphere for peace and sustainable national unity will remain elusive.

\section{Recommendations}

Following the exploration above, these recommendations are put forward;

1. The policy of quota system should be expunged from Nigeria educational system.

2. More schools should be built to accommodate the ever-increasing number of school applicants in the country.

3. To achieve the above, there is need for increased budgetary allocation to the educational sector in line with UNESCO's $26 \%$ benchmark

\section{References}

Antonio, D. E. (2019). Why peace and security are vital preconditions for sustainable development. Retrieved online from https://www.jm.undp.org17/08/2020.

Chang, L.W., Azizan, B. A. \& Amran, M. A. (2013). National unity at the university level: importance of civilizational dialogue and way forward. European Scientific Journal. 4, 173-186.

Enemuo, P. C. (2002). An analysis of globalization, privatization and commercialization and the challenges to Nigeria's foundation system. Nigerian Journal of Professional Research in Pedagogy and Psychology. 1(6) 99-105.

Federal Republic of Nigeria (1999). Constitution of the Federal Republic of Nigeria. Retrieved online on 23/07/20 from https://www.refworld.org/docid/44e344fa4.html.

Imhanlahimi, E. O. \& Maduewesi, B. U. (2006, September). Implementing panacea for admission crisis into Nigerian universities: An innovation diffusion plan. College Student Journal, 40(3), 34-48.

Odigwe, F. \& Swem, T. (2016). Nigerian university quota admission system and quality of education in universities in Cross River State, Nigeria. International Journal of Scientific Research in Education, 9 (4), $325-332$.

Ogoke, J. C., Onwuka, C. J. A. \& Enemuo, P. C. (2019). John Rawls theory of justice and the quota system of admission in Nigerian universities. Journal of Philosophy of Education. 29(1) 23-35.

Omeje, C. J., Egwa, E. I. \& Adikwa, V. O. (2016). Impact of quota system and catchment area policy on the university admissions in North Central Nigeria. Retrieved online on 22/01/19 from https://us.sagepub.com/en-us/nam/open-access-at-sage.

Onwubiko P. (2014). Perish admissions quota, federal character. Retrieved online on 20/01/19 from http:/www.mydailynewswatchng.com/2013/10/17/perish-admissions-quota-federal-character.

Onwuka, C. J. A. (1997). History of Nigerian education: Philosophical and political dimensions. Onitsha: Greenlink Publishers.

Onyekwelu, S. (2020). How cut off marks for Nigeria's unity schools maybe destroying quality. Retrieved online on 04/07/2020 from https://businessday.ng/educa/article/how-cut-off-marks-for-nigeria's-unity-schoolsmaybe-destroying-quality/amp/. 